\title{
The Unfavorable Influence of Transport on the Environment
}

\author{
R. Ličbinský* \& V. Adamec \\ Transport Research Centre, Brno, Czech Republic \\ *Corresponding author: roman.licbinsky@cdv.cz
}

DOI: $10.2478 / \mathrm{v} 10158-011-0010-\mathrm{z}$

\begin{abstract}
Transport has become an important factor in the development of the society, both in a positive (transport of people, raw materials, products, information) and a negative sense (traffic accidents, emissions). The rapid growth of transport capacity and the quantity of passenger and freight vehicles is reflected in the increasing environmental burden. Hence compounds emitted from all transport modes occur in all environmental components. These compounds often have adverse effects on ecosystems, animals, plants, and human health, and thus it is important to observe their occurrence in the environment.
\end{abstract}

KEY WORDS: transport, emissions, pollution, air, soil, water

\section{INTRODUCTION}

Air pollution is mostly spoken about when discussing the increasing environmental burden due to transport; however, the share of other components in the pollution of the environment, such as surface and ground water, soil, and biota, is central as well. The land use for the transport infrastructure and fragmentation of the countryside influences the migration of animals and bio-diversity and cannot be omitted. The production of vehicles and the considerable quantity of waste produced when they are scraped, containing a whole range of dangerous substances, represent a considerable impact on the environment. Whereas the above-mentioned consequences are long-term negative effects, the increasing mobility bring about a rise in the number of cases of acute pollution, mainly during traffic accidents. The accidents may have far-reaching consequences for the environment, particularly during the transportation of dangerous goods. In this respect, the issue of transport in relation to the environment and health of people has become more important in recent times.

\section{AIR POLLUTION}

One of the most important issues for transport is air pollution by emissions, mainly as a consequence of the significant risk they have in affecting human health. Recently, 
the share of automobile transport in air pollution has been rising significantly, which is particularly reflected in urban areas with high traffic volume. The source of emission of pollutants from vehicle engines into free air are exhaust gases formed during the combustion of fuel. They are complex mixtures containing hundreds of chemical compounds in various concentrations, contributing to long term warming of the atmosphere, the so-called "greenhouse effect", and often contain toxic, mutagen, and carcinogenic properties for humans. The most significant harmful pollutants contaminating the air from traffic can be divided into the limited compounds and unlimited compounds to which the emission limits refer. Carbon monoxide $(\mathrm{CO})$, nitrogen oxides $\left(\mathrm{NO}_{\mathrm{x}}\right)$, nonmethane volatile organic compounds (NM VOC), and particulate matter for diesel vehicles (particulate matter - PM) are rated as the limited pollutants. With the exception of PM in new vehicles, they have decreased as a consequence of stricter limits required by EURO standards, but considering the increasing volume of traffic, principally freight traffic, the total amount of emissions has grown nonetheless. The graphs depicting the development of the limited pollutant production by the individual modes of transport are shown in Figure 1 (Adamec, Dufek, 2002).
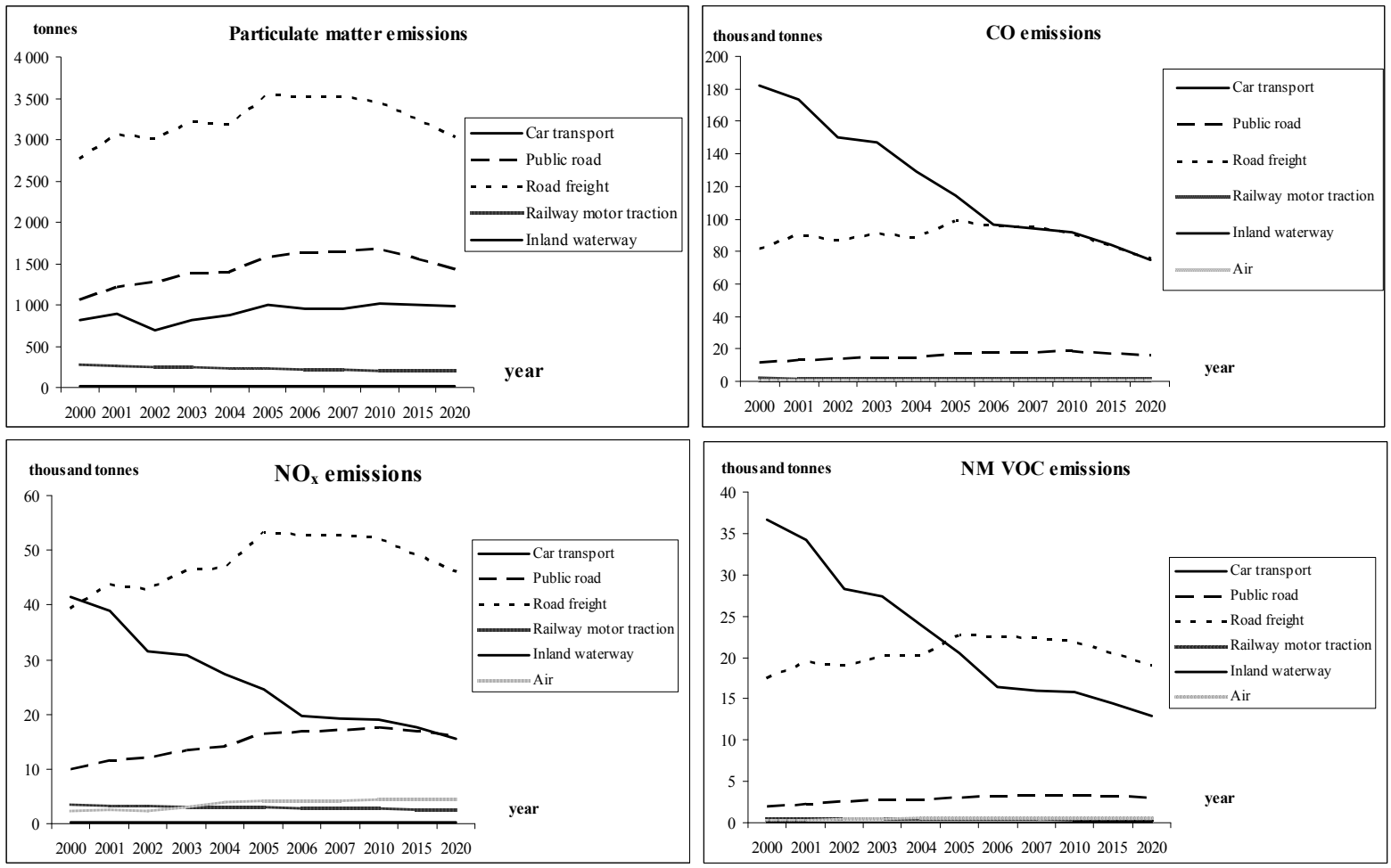

Figure 1: Production of limited pollutants by individual modes of transport.

The unlimited pollutants often have more serious effects on human health, but, currently, due to the lack of information about the compounds and far higher demands on the measuring technology, their production is not monitored. Within this group of pollutants we rate compounds contributing to long-term warming of the atmosphere, i.e. carbon dioxide $\left(\mathrm{CO}_{2}\right)$, methane $\left(\mathrm{CH}_{4}\right)$, and nitrous oxide $\left(\mathrm{N}_{2} \mathrm{O}\right)$. The other pollutants dangerous to human health, mainly produced during the imperfect combustion of fuel, are poly-aromatic hydrocarbons (PAH), phenols, ketones, tar, 1,3- butadiene and benzene, toluene, and xylenes (BTX). When fuel is burned polychlorinated dibenzo-p-dioxins/furans (PCDD/F) and polychlorinated biphenyls (PCB) could also be produced, in case of chlorine being present in the combustion system. The highest increase is recorded for the emissions of greenhouse gases, $\mathrm{CO}_{2}$ and $\mathrm{N}_{2} \mathrm{O}$, 
where newer vehicles show higher measured values than older types. The reason, in the case of $\mathrm{CO}_{2}$, is higher fuel consumption as a consequence of transport performance increase; in case of $\mathrm{N}_{2} \mathrm{O}$ emissions, the increase is caused by the introduction of catalytic converters. Some organic pollutants $(\mathrm{PAH})$ emitted by traffic which are dangerous mainly due to their toxic, genotoxic, and mutagen effects show a similar increasing trend. On the other hand, $\mathrm{CH}_{4}$ emissions are still decreasing because new vehicles have to meet stricter EURO limits. The $\mathrm{Pb}$ and $\mathrm{SO}_{2}$ emissions which depend on the quality of burnt fuel and their production by traffic is virtually negligible due to the legislative introduction of unleaded fuels on the market since 2001, and the gradual regulation of sulphur content in fuels since 2000. As it is apparent from Table 1, the share of transport on the total air pollution of CO is $37 \%$, of $\mathrm{NO}_{\mathrm{x}}$ approximately $30 \%$, and of volatile organic compounds $24 \%$. In comparison to 1993, there is an important increase in emissions of almost all monitored pollutants, predominantly PM which is based on the growth of transport performance.

Table 1: Transport share of the total air pollution (Jedlička et al., 2009).

\begin{tabular}{|c|c|c|c|c|c|c|c|c|c|c|c|c|c|}
\hline \multirow{2}{*}{$\begin{array}{c}\text { Pollutant } \\
{[\%]}\end{array}$} & \multicolumn{13}{|c|}{ Year } \\
\hline & 1990 & 1995 & 1997 & 1999 & 2000 & 2001 & 2002 & 2003 & 2004 & 2005 & 2006 & 2007 & \begin{tabular}{|l|l}
2008 \\
\end{tabular} \\
\hline $\mathrm{CO}_{2}$ & 6.05 & 8.07 & 9.16 & 10.94 & 9.53 & 10.17 & 11.08 & 12.24 & 13.14 & 15.33 & 14.97 & 15.33 & 15.76 \\
\hline CO & $\begin{array}{c}22.6 \\
7\end{array}$ & 34.87 & 39.64 & 45.04 & 43.58 & 43.60 & 47.10 & 45.21 & 41.76 & 47.33 & 44.12 & 40.20 & 43.06 \\
\hline $\mathrm{NO}_{\mathrm{x}}$ & $\begin{array}{c}19.5 \\
4\end{array}$ & 28.91 & 35.13 & 38.12 & 30.87 & 30.94 & 29.72 & 30.67 & 29.91 & 35.09 & 34.62 & 33.41 & 34.87 \\
\hline $\mathrm{N}_{2} \mathrm{O}$ & 2.70 & 4.76 & 5.72 & 5.90 & 6.20 & 5.46 & 6.35 & 8.07 & 8.41 & 10.01 & 10.48 & 10.37 & 9.60 \\
\hline $\mathrm{CH}_{4}$ & 0.20 & 0.32 & 0.36 & 0.39 & 0.37 & 0.34 & 0.32 & 0.35 & 0.35 & 0.33 & 0.30 & 0.31 & 0.30 \\
\hline VOC & $\begin{array}{c}12.9 \\
3\end{array}$ & 23.87 & 27.18 & 28.08 & 25.47 & 26.10 & 25.17 & 25.36 & 24.12 & 26.57 & 23.62 & 22.61 & 21.07 \\
\hline $\mathrm{SO}_{2}$ & 0.18 & 0.31 & 0.58 & 1.58 & 0.67 & 0.79 & 0.87 & 1.04 & 1.16 & 0.28 & 0.30 & 0.30 & 0.37 \\
\hline PM & 0.68 & 1.77 & 3.43 & 6.49 & 9.08 & 8.03 & 9.38 & 7.57 & 7.85 & 10.35 & 9.42 & 9.80 & 9.86 \\
\hline $\mathbf{P b}$ & $\begin{array}{c}80.0 \\
3\end{array}$ & 78.35 & 77.38 & 74.47 & 63.28 & 19.23 & 17.41 & 12.88 & 4.54 & 2.21 & 2.39 & 1.68 & 2.39 \\
\hline
\end{tabular}

In the effort to reduce dangerous exhaust gasses produced by burning fuel, catalytic convertors, used for the modification of automobile exhaust gases, were introduced in the first half of the 1990s. They are devices located in the exhaust pipe-line with a metal carrier which is covered by a catalytic substance on a highly porous layer. This substance allows to speed up the oxidation of the produced $\mathrm{CO}$ and hydrocarbons, and to reduce $\mathrm{NO}_{\mathrm{x}}$. So-called three-way controlled catalytic convertors are currently used the most; they use a mixture of platinum metals - platinum $(\mathrm{Pt})$, rhodium $(\mathrm{Rh})$ and palladium $(\mathrm{Pd})$ are contained as catalytically effective substances. Considering the fact that catalytic convertors are exposed to high temperature differences, the platinum metals are released into the environment (Farago et al., 1996, Gómez et al., 2001) which may have a negative influence on human health (Barefoot, 1997).

The above mentioned issue concerns the pollutants produced by the combustion processes of the so-called burning emissions. However, the release of other pollutants, especially PM, is connected with other processes as well, such as the abrasion of various exposed components (brake and clutch lining) when copper $(\mathrm{Cu})$, antimony $(\mathrm{Sb})$, barium $(\mathrm{Ba})$, iron $(\mathrm{Fe})$, aluminium $(\mathrm{Al})$, zinc $(\mathrm{Zn})$, molybdenum $(\mathrm{Mo})$, manganese $(\mathrm{Mn})$, magnesium $(\mathrm{Mg})$, cadmium $(\mathrm{Cd})$, and others are released into the air (Lamoree, Turner, 1999). The abrasion of tyres containing various types of rubber is a source of zinc; other metals like calcium 
$(\mathrm{Ca})$ and iron $(\mathrm{Fe})$, and elementary carbon are released as well. The whole range of metals also gets into the environment during the mechanical separation from the rusting automobile body-shell and street accessories (litter bins, road signs, lighting, crash barriers, etc.) (Janssen et al., 1997). The problem of resuspension of PM deposited on the roadway and in its near surroundings, initiated by passing vehicles or by the wind flow poses a significant burden to the air quality (Nicholson, 1988). The dust on the road pavement contains particles of bigger fractions which are composed of both metals of a geological origin from the surrounding soil (Al, $\mathrm{Si}, \mathrm{Ca}, \mathrm{Mg}$ ) and the above-mentioned metals from the operation of automobiles (Janssen et al., 1997, Vallius, 2005). The particles of chemical (salt) and inert material (sand, gravel, slag) also play an indispensable role in the road maintenance during the winter period, as well as falling-off dirt from vehicles and falling-off parts of transported material. We speak of the non-combustible emissions in this case. The brief overview of the pollutants produced by traffic, including their potential creation, is mentioned in the following Table 2.

Table 2: Sources and characteristics of selected air pollutants in connection with traffic (Adamec et al., 2005).

\begin{tabular}{|c|c|}
\hline Harmful compound & Production in traffic \\
\hline $\begin{array}{l}\text { Carbon dioxide } \\
\text { (CO2) }\end{array}$ & $\begin{array}{l}\text { Fuel combustion containing carbon. } \\
\text { Petrol passenger cars produce } 3183 \mathrm{~g} \text { of this pollutant by combusting } \\
1 \mathrm{~kg} \text { of fuel, the same for diesel engines and freight. }\end{array}$ \\
\hline $\begin{array}{l}\text { Carbon monoxide } \\
\text { (CO) }\end{array}$ & $\begin{array}{l}\text { Fuel combustion containing carbon with the insufficient access of air } \\
\text { or at high temperatures. Petrol passenger cars produce } 18-168 \mathrm{~g} \\
\text { of this pollutant per kg of fuel, diesel } 2.5 \text { to } 9 \mathrm{~g} \cdot \mathrm{kg}^{-1} \text { of fuel. Trucks } 7 \\
\text { to } 221 \mathrm{~g} \cdot \mathrm{kg}^{-1} \text { of fuel. It is always dependent on the observation } \\
\text { of the EURO limits. }\end{array}$ \\
\hline $\begin{array}{l}\text { Sulfur dioxide } \\
\left(\mathrm{SO}_{2}\right)\end{array}$ & $\begin{array}{l}\text { Fuel combustion containing sulphur, however, the production } \\
\text { is currently minimum due to quality fuels. }\end{array}$ \\
\hline $\begin{array}{l}\text { Nitrogen oxides } \\
\quad\left(\mathrm{NO}_{\mathrm{x}}\right)\end{array}$ & $\begin{array}{l}\text { Combustion of fuel and air mixture, oxidation of the atmospheric } \\
\text { nitrogen at high temperatures. Petrol passenger cars produce } 1 \text { to } 45 \mathrm{~g} \\
\text { of this pollutant per kg of fuel, diesel } 4.3 \text { to } 18.3 \mathrm{~g} \cdot \mathrm{kg}^{-1} \text {, trucks } 10 \\
\text { to } 93,3 \mathrm{~g} \cdot \mathrm{kg}^{-1} \text { of fuel. }\end{array}$ \\
\hline $\begin{array}{l}\text { Nitrous oxide } \\
\qquad\left(\mathrm{N}_{2} \mathrm{O}\right)\end{array}$ & $\begin{array}{l}\text { Reaction of atmospheric nitrogen with atmospheric hydrogen mainly } \\
\text { in presence of catalytic convertors from the group of platinum metals. } \\
\text { Petrol passenger cars produce } 0.3 \text { to } 1.1 \mathrm{~g} \text { of this pollutant per kg } \\
\text { of fuel, diesel } 0.1 \text { to } 0.3 \mathrm{~g} . \mathrm{kg}^{-1} \text { and the same holds for trucks. }\end{array}$ \\
\hline$\underset{\left(\mathbf{N H}_{3}\right)}{\operatorname{Ammonia}}$ & $\begin{array}{l}\text { Reaction of atmospheric nitrogen with hydrogen contained } \\
\text { in the fuel. Petrol passenger cars produce even } 1.4 \mathrm{~g} \text { of this pollutant } \\
\text { per kg of fuel, diesel and trucks then approximately hundredths } \mathrm{g} \cdot \mathrm{kg}^{-1} \\
\text { of fuel. }\end{array}$ \\
\hline $\begin{array}{l}\text { Ozone } \\
\left(\mathrm{O}_{3}\right)\end{array}$ & $\begin{array}{l}\text { Secondary chain radical reactions in the earthbound layers } \\
\text { of the atmosphere from the molecular hydrogen in the presence } \\
\text { of the exhaust gases components, nitrogen oxides and liquid } \\
\text { hydrocarbons under the influence of solar radiation. }\end{array}$ \\
\hline $\begin{array}{c}\text { Lead } \\
(\mathrm{Pb})\end{array}$ & $\begin{array}{l}\text { In the past, mainly combustion of leaded petrol in which it was } \\
\text { present as tetraethyl-lead. Anti-knocks have not been used } \\
\text { since } 2001 \text { on its basis. Its sources are currently balancing weights } \\
\text { of the tyres, grease, oils, and particles produced by wearing out } \\
\text { of bearings. }\end{array}$ \\
\hline
\end{tabular}




\begin{tabular}{|c|c|}
\hline Harmful compound & Production in traffic \\
\hline $\begin{array}{c}\text { Cadmium } \\
(\mathbf{C d})\end{array}$ & Wear out of various car components. \\
\hline $\begin{array}{l}\text { Nickel } \\
\text { (Ni) }\end{array}$ & Abrasion of brake pads and various stressed joints. \\
\hline $\begin{array}{c}\text { Chrome } \\
(\mathrm{Cr})\end{array}$ & $\begin{array}{l}\text { Mechanical separation from rotating parts of the engine parts } \\
\text { and the brake pads. }\end{array}$ \\
\hline $\begin{array}{l}\text { Platinum metals } \\
\text { (platinum Pt, } \\
\text { rhodium -Rh, } \\
\text { palladium - Pd) }\end{array}$ & Released from car catalytic convertors. \\
\hline $\begin{array}{c}\text { Polycyclical } \\
\text { aromatic } \\
\text { hydrocarbons } \\
\text { (PAH) }\end{array}$ & $\begin{array}{l}\text { Imperfect fuel combustion, or, abrasion of the road pavement surface. } \\
\text { Diesel and trucks produce hundredths of grams of this pollutant } \\
\text { group out of } 1 \mathrm{~kg} \text { of fuel by its combusting, in case of gas, } \\
\text { approximately thousandths of g. } \mathrm{kg}^{-1} \text { of fuel. }\end{array}$ \\
\hline $\begin{array}{l}\text { Methane } \\
\left(\mathrm{CH}_{4}\right)\end{array}$ & $\begin{array}{l}\text { Imperfect fuel combustion. Petrol passenger cars produce } 0.1 \text { to } 0.9 \mathrm{~g} \\
\text { of this pollutant per kg of fuel, diesel hundredths of grams and trucks } \\
\text { from } 0.1 \text { to } 0.6 \mathrm{~g} \cdot \mathrm{kg}^{-1} \text { of fuel. }\end{array}$ \\
\hline $\begin{array}{l}\text { Volatile organic } \\
\text { compounds } \\
\text { (NM VOC) } \\
\end{array}$ & $\begin{array}{l}\text { Fuels combustion and evaporation from the cars. Petrol passenger } \\
\text { cars produce } 1.3 \text { to } 40 \mathrm{~g} \text { of this pollutant per kg of fuel, diesel } 0.6 \\
\text { to } 2.3 \mathrm{~g} \cdot \mathrm{kg}^{-1} \text {, trucks } 3 \text { to } 42 \mathrm{~g} . \mathrm{kg}^{-1} \text { of fuel. }\end{array}$ \\
\hline $\begin{array}{l}\text { Benzene } \\
\left(\mathrm{C}_{6} \mathrm{H}_{6}\right)\end{array}$ & $\begin{array}{l}\text { Fuel combustion and evaporation during their manipulation, } \\
\text { distribution and storage. In Europe it is present in automobile petrol } \\
\text { in share of around } 5 \% \text {, sometimes even more than } 10 \% \text {. }\end{array}$ \\
\hline $\begin{array}{c}\text { Toluene } \\
\left(\mathrm{C}_{6} \mathrm{H}_{5}-\mathrm{CH}_{3}\right) \\
\end{array}$ & $\begin{array}{l}\text { Combustion of fuel containing mixtures with benzene and xylene } \\
\text { used as an additive to increase the octane rating of petrol. }\end{array}$ \\
\hline $\begin{array}{c}\text { Styrene } \\
\left(\mathrm{C}_{6} \mathrm{H}_{5}-\mathrm{CH}=\mathrm{CH}_{2}\right)\end{array}$ & Imperfect combustion processes. \\
\hline $\begin{array}{l}\text { Formaldehyde } \\
\left(\mathrm{H}_{2} \mathrm{C}=\mathrm{O}\right)\end{array}$ & Imperfect fuel combustion. \\
\hline $\begin{array}{c}\text { 1,3-butadiene } \\
\left(\mathrm{CH}_{2}=\mathrm{CH}-\right. \\
\left.\mathrm{CH}=\mathrm{CH}_{2}\right)\end{array}$ & Imperfect fuel combustion mainly with high content of olefins. \\
\hline $\begin{array}{l}\text { Particulate matter } \\
\text { (PM) }\end{array}$ & $\begin{array}{l}\mathrm{PM}_{2.5-10} \text { (large fraction) - predominantly swirling dust from road } \\
\text { pavements, abrasion of tyres, and in the combustion processes. } \\
\text { It stays in the close proximity of the source. } \\
\mathrm{PM}_{2.5} \text { (fine fraction) - as a consequence of chemical reactions } \\
\text { in the combustion of fuels. } \\
\mathrm{PM}_{0.02} \text { (ultra-fine fraction) - from gas emissions during combustion } \\
\text { processes. It could be transferred by air even on long distances.. } \\
\mathrm{PM}_{0.01} \text { (nano-particles) - fuel combustion, mainly in petrol engines. } \\
\text { Diesel passenger cars produce } 0.3 \text { to } 4.8 \mathrm{~g} \text { of this pollutant per kg } \\
\text { of fuel, freight then } 0 . \text { up to } 6.3 \mathrm{~g} \cdot \mathrm{kg}^{-1} \text { fuel, depending on observing } \\
\text { the EURO limit. }\end{array}$ \\
\hline $\begin{array}{l}\text { Polychlorinated } \\
\text { dibenzo-p-dioxins } \\
\text { and dibenzofurans } \\
(\text { PCDD/F) }\end{array}$ & $\begin{array}{l}\text { Oxidation of carbon particles in burnt gases at the temperatures } \\
\text { of } 250-350^{\circ} \mathrm{C} \text { in the presence of hydrogen, water vapour } \\
\text { and chlorine. }\end{array}$ \\
\hline $\begin{array}{l}\text { Polychlorinated } \\
\text { biphenyls } \\
\text { (PCB) }\end{array}$ & $\begin{array}{l}\text { Synthesis of particles of carbon, hydrogen, water vapour } \\
\text { in the presence of chlorine. }\end{array}$ \\
\hline
\end{tabular}


Particulate matter (PM) have come into the spotlight lately, due to their negative influence on human health and their increasing content in the air, mainly in urban areas. Therefore, greater attention is paid to PM in this chapter.

PM contains particles of solid and liquid material of a size from $1 \mathrm{~nm}$ up to $100 \mathrm{~mm}$ staying in the air for a certain period of time. We can see them in the atmosphere in the form of a complicated heterogeneous mixture, in terms of particle size and their chemical composition. PM are characterized by their specific physical (form, size, electric charge, surface of the particles, and solubility) and chemical properties (inorganic and organic components) which depend on their source, mechanism of origin and other conditions which influence their occurrence (distance from resources, meteorological conditions). Out of the physical properties a representation of individual size fractions of the particles is principally critical for the emitted particles, which contain ultra fine, fine, and large fractions as well. Out of the total quantity of the total suspended particulate matter (TSP) in the air, $60-65 \%$ are formed by fraction of $\mathrm{PM}_{10}$ particles, which are particles of a diameter lower than $10 \mu \mathrm{m} .72 \% \mathrm{PM}_{10}$ fraction is formed by particles of a aerodynamic diameter lower than $2.5 \mu \mathrm{m}$ (fraction $\mathrm{PM}_{2.5}$ ) and smaller particles in the $\mathrm{PM}_{1.0}$ fraction (aerodynamic diameter under $1 \mu \mathrm{m}$ ) make $52 \%$ (Harrison et al., 2003). In Figure 2 there are photos of PM taken with the use of a scanning electron microscope (SEM).

The possible effects on human health, and the possible health risks which they may have on the exposed population, are connected with the size of particles and their composition (Weijer et al., 2001). The dangers of PM do not lie only in their mechanical properties but mainly in the hazardous organic content (particularly $\mathrm{PAH}$ ) or in a whole range of inorganic pollutants, such as molybdenum, copper, nickel, cadmium, platinum (Adamec et al., 2004, Krzyzanowsky et al., 2005, Adamec et al., 2006).
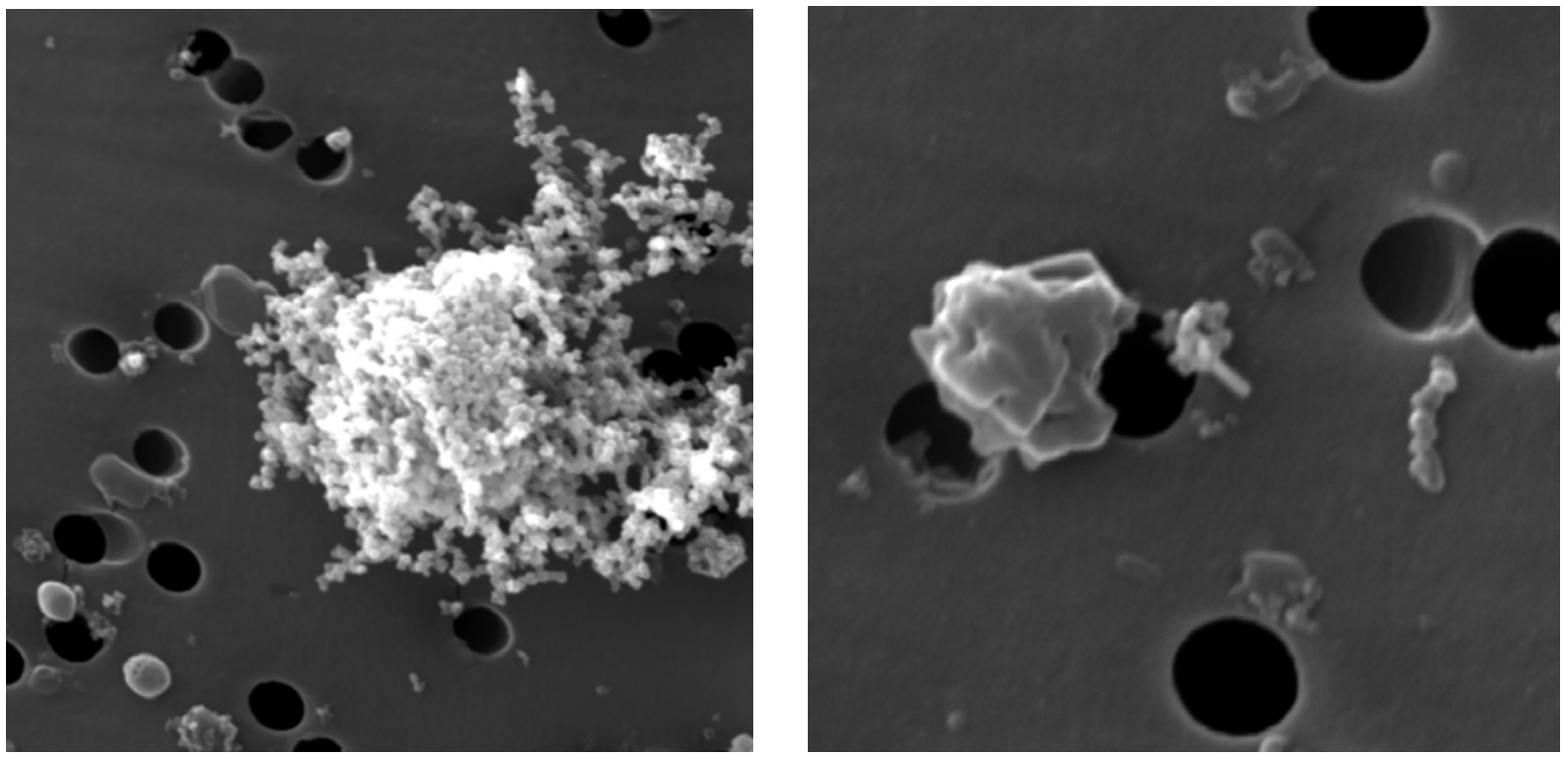

Figure 2: Left photo - PM produced from fuel combustion (amplification 30 thousand), right photo - PM produced by mechanical separation (amplification 70 thousand).

The total content of particles in the air, apart from the particles emitted directly from the primary resources (traffic, industry), is contributed by the solid particles in a very significant way. This process significantly contributes to their content increase in the air 
and according to various studies, it could be a source of even $60 \%$ of particles of $\mathrm{PM}_{10}$ fraction (Braaten et al., 1990). Blowing the sedimentation particles as a consequence of passing cars depends on specific local conditions, on road surface quality, vehicle speed, vehicle weight, and air humidity. The dangers of the re-suspended particles lie mainly in the sorption of other pollutants onto their surface in case of their longer stay on the road or in its surroundings.

PM can be removed from the air by wet deposition during rain, when there is a "washout" of mainly large particles with aerodynamic diameter over $5 \mu \mathrm{m}$, or by the change of the air masses, when "clean" air comes to the given area. Another mechanism for eliminating the particles from the air in urban areas is their deposition when dissociation of the particles from the air appears as a consequence of their contact with a solid or liquid surface. The presence of vegetation which greatly enhances the circulation of air in the lowest layer of the terrain surface, supports this deposition considerably. In densely built-up urban areas, grass areas, which are often the only alternative for permanent particle deposition in these places, play an important role in the particle catching. We can generally conclude that particles of smaller dimensions (under $1 \mu \mathrm{m}$ ) are caught more easily, whereas particles larger than $5 \mu \mathrm{m}$, tend to be reflected by the surface.

Currently, the research in the field of nano-particles, which are particles with dimensions under $100 \mathrm{~nm}$ and have some special properties, like bio-persistence, adsorption, or diffusion, and are the subject matter for a range of world research institutes, is developing very quickly. Nano-particles are produced by both natural processes (erosion) and the anthropogenic activities of people (fossil fuel burning, mining, production of nano-materials, etc.) and they are released into the environment. Then they are exposed to various biological, chemical, and physical changes and get in contact with living organisms (Dreher et al., 2003). Currently, the concentrations of ultra-fine particles in the air of large urben areas are monitored and analyzed only at some stations in Europe due to very expensive equipment.

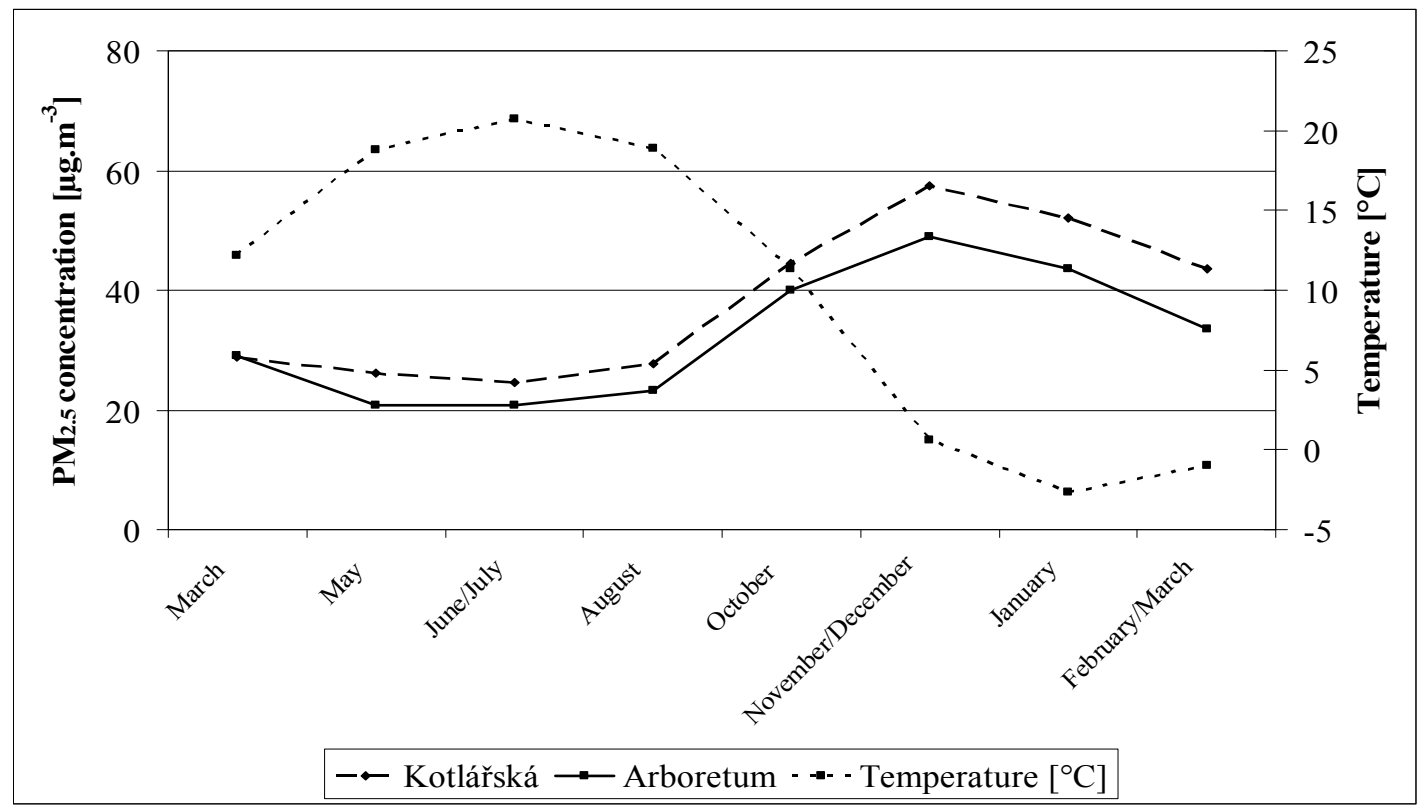

Figure 3: Development of $\mathbf{P M}_{2.5}$ concentration and temperatures (Adamec et al., 2007).

The evaluation of the level of air pollution comes from the monitoring of the polluting compound concentration in the atmosphere ground layer in the network of measuring stations. 
The evaluation of air pollution is based on the relation of measured imission values to corresponding imission limits and target imission limits. In 2006, the government resolution No. 597/2006 Sb., came into force following the Act on air (Act No. 86/2002 Sb.), which determines the imission limits which are in accordance with the requirements of the EU directives on the environment quality. The regular measurements of particulate matter (mainly fractions of $\mathrm{PM}_{10}$ ) take place in the Czech Republic in connection with this legislative framework; in 2006 the measurements were executed in 148 localities. These places represent various fields in terms of landscape morphology, presence of residential areas, industrial enterprises, etc. The background localities which are of highest numbers are located mostly in the residential zones of the cities, in rural, and natural areas. Industry is considered to be a dominant source of particulate matter in 12 localities. 33 localities are directly influenced by traffic. In these cases, the measuring devices are close to roads and junctions with high traffic volumes. The primary sources of particulate matter are processes related to traffic in these places, mainly fossil fuel combustion in car engines, and the mechanical production of the particles by tyre abrasion, brake pads, and tarmac surface of roads. The monitoring network stations are operated by The Czech Hydrometeorological Institute, Health Institutes of the given areas, or municipal authorities of the urban areas where the measurements take place. Measured data are then freely available on the websites of the Czech Hydrometeorological Institute ČHMÚ.

As is clear from certain long-term measurements (Adamec et al., 2005, Adamec et al., 2007) of concentrations of $\mathrm{PM}_{2.5}$ fine fraction, the determined annual average concentrations (38.07 $\mu \mathrm{g} . \mathrm{m}^{-3}$ resp. $32.49 \mu \mathrm{g} \cdot \mathrm{m}^{-3}$ ) are significantly higher than limit concentrations for this pollutant $\left(25 \mu \mathrm{g} . \mathrm{m}^{-3}\right)$ proposed in the prepared $\mathrm{EU}$ directive for air quality. The results also show the significant seasonal dependence of $\mathrm{PM}_{2.5}$ concentrations, (Figure 3) when in the lowest measured temperatures the highest concentrations were determined, this also worked vice versa. This difference could have been caused by the loss of volatile components of PM (e.g. ammonium salts) in summer months; these components coagulate and could be caught by filters in periods of low temperatures. However, the above-described trend could have a connection with other aspects as well, mainly with vertical atmosphere stability. Thanks to better ventilation, the particles are better dispersed during hot periods (convection), whereas during colder months (inversion) the ventilation is limited, so PM "accumulation" in the lower layers of the atmosphere occurs near the place of their origin. Some local sources, such as fireplaces and other sources of heating, could also significantly participate in the presence of particles in winter.

The knowledge of distribution of the individual size fractions of PM, i.e. the representation of individual particles in the range of sizes 2.5 to $10 \mu \mathrm{m}, 1$ to $2.5 \mu \mathrm{m}$, and 0 to $1 \mu \mathrm{m}$ in the total particle content smaller than $10 \mu \mathrm{m}$, is very important for understanding PM behaviour, and, mainly, for an estimation of the health risks. The share of the individual fractions in $\mathrm{PM}_{10}$ during the summer period is shown in Figure 4, during autumn at the turn of November and December in Figure 4. The share of finer PM2.5 fractions in the total concentration of $\mathrm{PM}_{10}$ is higher during cold periods when these particles make $92.9 \%$ of $\mathrm{PM}_{10}$, whereas during hot periods of year, this share was only $59 \%$ (Adamec et al., 2007). The annual average concentrations of $\mathrm{PM}_{10}\left(50.24 \mu \mathrm{g}^{-\mathrm{m}^{-3}}\right.$ resp. $35.56 \mu \mathrm{g} . \mathrm{m}^{-3}$ ) determined within long-term measurements are in accordance with similar towns and cities in Europe, where the concentrations reach values between $44.4 \mu \mathrm{g}^{-\mathrm{m}^{-3}}$ $53.8 \mu \mathrm{g} . \mathrm{m}^{-3}$ (Martuzzi et al., 2002). The following concentrations of PAH in the chosen risk elements - cadmium (Cd), arsenic (As), chromium (Cr), nickel (Ni), Mo, Pb, linked to their surface, correspond to values determined in the environment with medium traffic volume or industry in a number of European cities, such as Manchester, London (Harrison 
et al., 2003), Birmingham (Harrison et al., 1996), Helsinki (Yli-Tuomi et al., 2005), and Budapest (Salma, Maenhaut, 2006).
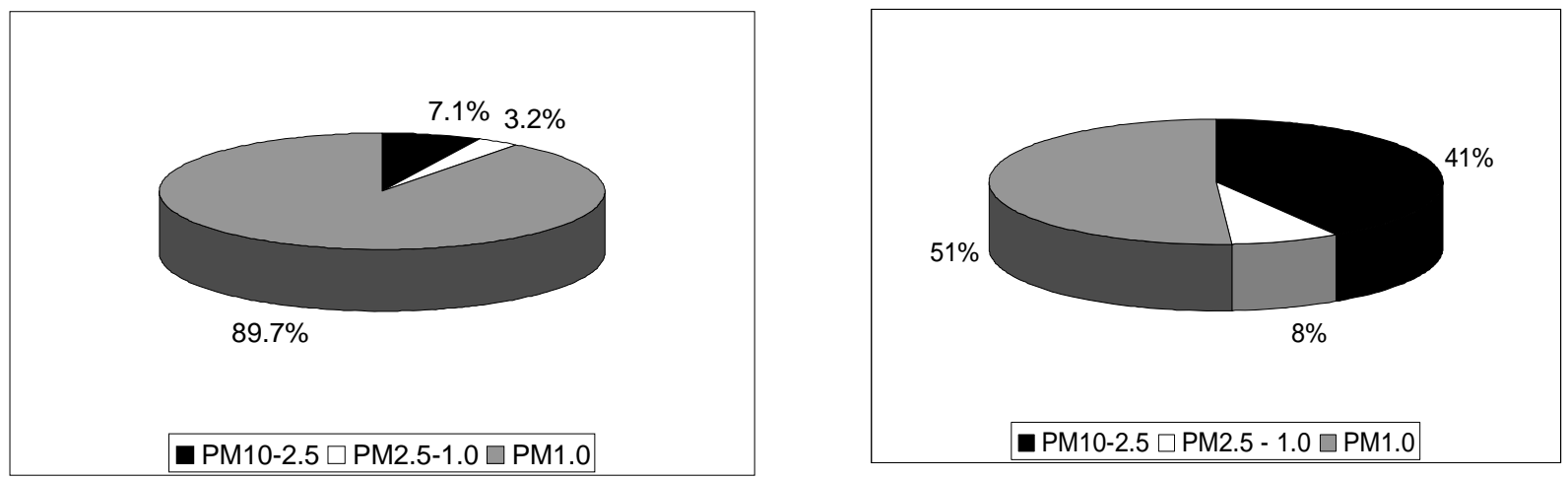

Figure 4: The share of the individual PM10 fractions during the period 25 June -5 July 2007 (left graph) and during the period 28 November - 5 December 2007 (right graph).

As has already been mentioned, the evaluation of air pollution monitors the relationship of air pollution and the relevant limit values (Table 3), which are determined in connection with the Clean Air Act in the Czech Republic (Act No. 86/2002, Sb.) by the government resolution No. 597/2006, Sb., as amended. The pollution limits are in accordance with the requirements of the EU directives on the environment air quality valid in all EU member states (Act No. 86/2002, Sb.).

The overall air pollution is evaluated by emission balances which compare the production of selected harmful compounds from all sources. The basis for the national emission balance is a Register of Emissions and Air Polluters (REZZO), which has been methodically conducted and operated by The Czech Hydrometeorological Institute (ČHMÚ) since 2003. The pollution sources are recorded in four categories - large, medium, small, and mobile in the REZZO database.

Table 3: Values of pollution limits valid in the Czech Republic for selected pollutants (government resolution No. 597/2006, Sb.).

\begin{tabular}{|l|l|}
\hline \multicolumn{1}{|c|}{ Pollutant } & \multicolumn{1}{c|}{ Valid imission limit in the Czech Republic } \\
\hline PM $_{\mathbf{1 0}}$ & $\begin{array}{l}\text { Annual average concentration of } 40 \mu \mathrm{g} \cdot \mathrm{m}^{-3} \\
\text { maximum 24-hours concentration of } 50 \mu \mathrm{g} \cdot \mathrm{m}^{-3} \\
\text { (maximum number of exceeded values per year 35 ) }\end{array}$ \\
\hline NO $_{\mathbf{2}}$ & $\begin{array}{l}\text { Annual average concentration of } 40 \mu \mathrm{g} \cdot \mathrm{m}^{-3} \\
\text { maximum } 1 \text { hour concentration of } 200 \mu \mathrm{g} \cdot \mathrm{m}^{-3} \\
\text { (maximum number of exceeded values per year 18) }\end{array}$ \\
\hline NO $_{\mathbf{x}}$ & Annual average concentration of $30 \mu \mathrm{g} \cdot \mathrm{m}^{-3}$ (to protect vegetation) \\
\hline CO & maximum daily 8-hour concentration of $10 \mathrm{mg} \cdot \mathrm{m}^{-3}$ \\
\hline Benzene & Annual average concentration of $5 \mu \mathrm{g} \cdot \mathrm{m}^{-3}$ \\
\hline Benzo(a)pyrene & Annual average concentration of $1 \mathrm{ng} \cdot \mathrm{m}^{-3}$ \\
\hline Lead & Annual average concentration of $0.5 \mu \mathrm{g} \cdot \mathrm{m}^{-3}$ \\
\hline
\end{tabular}


The emissions from traffic, together with emissions from agriculture, forestry, civil engineering industry, and the military, are a part of the mobile sources balance. These emissions are calculated as a product of the so-called active data and emission factors. The active data are expressed as consumption of fuel per a kilometre of a given category of means of transport. The emission factor is an emission quantity of a given pollutant which refers to a weight unit of a given fuel or driven distance unit. The CDV methodology (Dufek et al., 2001) based on the calculations of emissions from the consumption of fuels, is used for the determination of emissions on the national and regional levels. The program MEFA, which calculates the emission factors by referring to $1 \mathrm{~km}$ of the driven distance (Šebor et al., 2002), is used at the local level.

In Table 4, there is an overview of the emission factors of selected pollutants concerning petrol and diesel passenger cars which meet the EURO 3 limits, e.g. Škoda Fabia, produced between 2001 and 2005. The emission factor for heavy vehicles is also mentioned here as a comparison from the same production date. The emission PM factors for petrol passenger cars are not determined, considering the fact that these types of engines produce very fine, or even ultra-fine, particles, whose production is not currently monitored due to high costs of the measuring equipment.

Table 4: Emission factors for various types of vehicles.

\begin{tabular}{|l|c|c|c|c|c|c|c|c|c|}
\hline $\begin{array}{c}\text { Emission } \\
\text { factors } \\
\text { [g.kg-1 fuel] }\end{array}$ & \multicolumn{5}{|c|}{ limited pollutants } & \multicolumn{5}{c|}{ unlimited pollutants } \\
\hline EURO 3 & PM & CO & $\mathbf{N O}_{\mathbf{x}}$ & NM VOC & CO & $\mathbf{N}_{\mathbf{2}} \mathbf{O}$ & $\mathbf{C H}_{4}$ & PAH & $\mathbf{N H}_{\mathbf{3}}$ \\
\hline $\begin{array}{l}\text { Petrol } \\
\text { passenger car }\end{array}$ & $\mathrm{X}$ & 18.21 & 1.07 & 1.27 & 3.183 & 1.10 & 0.10 & $\begin{array}{c}0.00225 \\
6\end{array}$ & 1.333 \\
\hline $\begin{array}{l}\text { Diesel } \\
\text { passenger car }\end{array}$ & 0.28 & 2.42 & 4.25 & 0.57 & 3.138 & 0.25 & 0.08 & $\begin{array}{c}0.02083 \\
2\end{array}$ & 0.016 \\
\hline Heavy vehicles & 0.41 & 7.33 & 10.26 & 2.71 & 3.138 & 0.25 & 0.15 & 0.0016 & 0.012 \\
\hline
\end{tabular}

Legend: $X=$ not determined

\section{WATER POLLUTION}

The surface and ground water form an important component of the environment and are one of the fundamental raw material sources necessary for maintaing life on Earth. However, human influence gradually leads to its quality reduction, when one of the negative factors affecting its quality are various modes of transport. The seas and oceans may be contaminated by ships, mainly as a consequence of huge tankers accidents when considerable amount of oil leaks into water which brings with it extensive pollution with serious environmental effects. The cases of the tankers Exxon Valdez (1989) and Prestige (2002) are among the most infamous accidents. A source of long-term pollution may also come from large ports through handling with transported material or during vessel repairs.

In connection with the pollution of water, both surface and groundwater, the issue of rail transport come into consideration. The pollution sources are, in this case, rail transport, power supply, and switching stations, places for the washing of rail cars, fuel stations; and in the case of diesel traction, the railway vehicles themselves, and their accidents on the rail tracks. The pollution by road transport could also have a random character in the form of car accidents with a leakage of fuel, motor oils, operating liquids, and other pollutants, but also through long-term impact of exhaust gases, abrasions 
of the tyres and road pavement surface, and fuel dripping. The indicators of the maximum permissible level of surface and ground water pollution are evaluated by the government resolution No. 61/2003, Sb.,as amended, and the the guidelines of the Ministry of the Environment of the Czech Republic, Appendix of the Bulletin of the Ministry of the Environment, No. 8, year 6, 1996.

\subsection{Surface water}

The pollution of surface water is caused by rain water drained from the road surface with a high traffic volume, mainly motorways and dual carriageways. The pollution is highly dependent on the amount of rain falling on motorway surface where the concentrations of the pollutants in the "first drain" are the highest after rainfalls and after a over time it rapidly decreases, whereas, the pollution is directly reflected behind the drain where the drained water is not sufficiently diluted yet. The whole range of pollutants, including metal elements and suspended solid particles produced from the operation of traffic, mainly through the abrasion of road pavement surfaces and tyres, was identified in the surface drainage outlet, (Sansalone, Buchberger, 1995). The pollutants could also come from the materials used for road maintenance, lay-bys, and car parks mainly during winter, when the contamination could be connected with the application of defrosting agents and antifreeze mixtures. A key source of pollutants are also the leaks and spills of fuel when, besides the whole range of organic pollutants like PAH, hydrocarbons and metals are released into the environment (Shinya et al., 2000). Another important risk of possible environmental contamination is represented by filling stations, in whose proximity and on the adjacent car parks the highest concentrations of PAH were found (Smith et al, 2000). The motorways are, according to a range of studies, also the main source of chlorides which do not drain away through the watercourse, but they mainly soak into the soil and rock environments where, under certain conditions, their accumulation and subsequent gradual washout occurs (Runge et al., 1989).

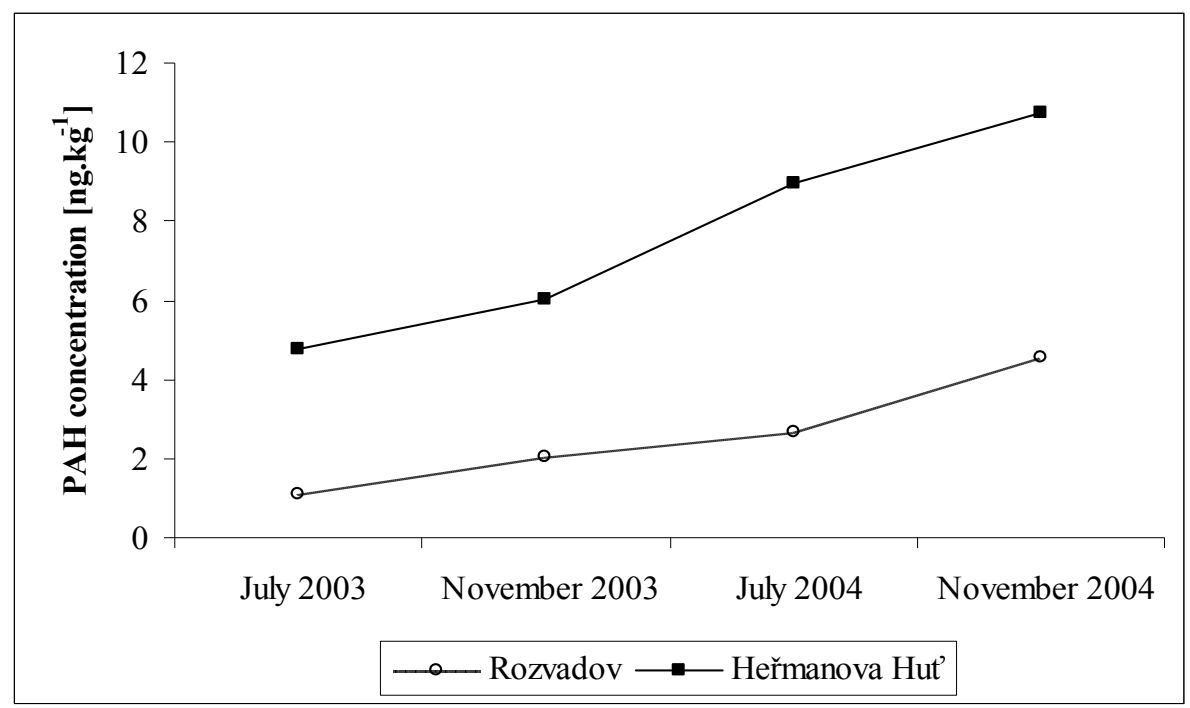

Figure 5: Development of PAH concentrations.

In order to monitor the pollution of the drained water, a method of passive sampling with the help of semi-permeable membranes (SPMD) is often used. This method simulates 
the diffusion process via bio-membranes, which are considered to be crucial in the bioconcentration of the pollutants in living organisms. This method was also used for the monitoring of the pollution level of the water drained from motorway D5 into retention tanks. From the graph in Figure 5, the growth of the PAH concentration within the monitored period is easily apparent (Adamec et al., 2005), nevertheless, the set contents are lower than figures recorded in some foreign studies, and so far they do not exceed the limit concentrations set by the government Directive No. 61/2003 (NV, 2003), as amended.

\subsection{Ground water}

A similar problem, although not that urgent, is the contamination of the ground water by pollutants from materials used for road building. During the construction a whole range of materials, which met the technical construction requirements at that time, was used in the past; however, currently, as a consequence of stricter measures (limits), they could have a negative influence on the environment components and human health (Legret et al., 2005). Especially the migrant water in the roadway, drained by drainage systems, could be contaminated by pollutants released from the construction materials. However, this process depends on a lot of factors, like the subgrade type and the surrounding terrain characteristics, ground water management, capillary rise of ground water level, and the amount of precipitation which could penetrate the roadway, mainly as a consequence of damage to its surface layer (cracks, fissures). In the Czech Republic, the construction of asphalt roads uses unmodified and modified road asphalts made of raw materials which influence their final properties, i.e. influence a release of hazardous substances to the environment as well. These could form a basic part of the produced binder (e.g. PAHs, hydrocarbons) or could be added to modify and prepare better asphalt properties, e.g. the reduction of plastic deformations. For these purposes, e.g. elementary sulphur, polyethylene, polypropylene, powder polyvinyl chloride, and others are used. The permeating of some PAHs and metals from the sample asphalt surface and other construction materials are shown in some foreign studies and their results are in correlation with the results of Czech researches (Ličbinský et al., 2007). The release of pollutants from the used materials could currently be considered low, depending on the pollutant properties and on the primary content of the organic and inorganic pollutants in the given material. The major source of pollution lately, due to the increasing traffic volume, are traffic accidents with a leakage of fuel, motor oils, operating liquids, and transported dangerous goods, such as acids, lyes, and other chemicals.

\section{SOIL POLLUTION}

As in the case of water pollution, the threat to soil quality in the road surroundings occurs basically by three sorces: by long-term pollution, caused by everyday road traffic, by seasonal pollution, mainly through the influence of road winter maintenance, and by traffic accidents, when the leaking of environmentally harmful materials occurs.

Long-term soil contamination in the surroundings of roads is connected mainly with the pollutant drainage from the road surface and the splashing of water caused by passing cars to the surroundings. Thus, the soil could be contaminated by PAH and its derivatives, particularly nitrated ones (nitro-PAH), hydrocarbons, and some metals as well. Its contamination may also occur through using abrasive winter maintenance materials and chemical defrosting materials. For this purpose sodium chloride, calcium chloride, and their mixtures, as of spreading, sprays or dampers (sprinkling salt), are used; however, 
during their application it is not possible to prevent dispersion around the road and thus contamination with chlorides. Subsequently, their presence causes the corrosion of metal elements of the road equipment and the increased release of pollutants from their protective coating, which could lead to subsequent pollution by heavy metals. The issue of soil contamination is also closely related to pollutants permeating from roadways when under the influence of water soaking in the road body, their permeating and subsequent transport to the environment occurs. The soil contamination is particularly problematic in large urban areas with a high volume of car transport. Metals from the platinum group (PGE) like platinum (Pt), palladium (Pd), and rhodium $(\mathrm{Rh})$, which are among materials worth mentioning, are classified as toxic metals, and their increasing concentrations could represent a serious risk nowadays. The concentration of $\mathrm{Pt}$ emitted from car catalytic converters at sites with high traffic volumes in the Czech Republic, ranges from $9.20-21.57 \mu \mathrm{g} . \mathrm{kg}^{-1}$ and is comparable with the levels of other European cities (Zereini et al., 1997). At these sites, higher contents of PAH, higher even than in the close proximity of motorways, were found (Tuháčková et al., 2001).

Table 5: Land use as a consequence of road construction (Jedlička et al., 2009).

\begin{tabular}{|l|c|c|c|c|c|c|c|c|c|}
\hline \multicolumn{1}{|c|}{ Region } & $\mathbf{2 0 0 0}$ & $\mathbf{2 0 0 1}$ & $\mathbf{2 0 0 2}$ & $\mathbf{2 0 0 3}$ & $\mathbf{2 0 0 4}$ & $\mathbf{2 0 0 5}$ & $\mathbf{2 0 0 6}$ & $\mathbf{2 0 0 7}$ & $\mathbf{2 0 0 8}$ \\
\hline Středočeský & 12.74 & 71.31 & 89.75 & 61.10 & 142.62 & 317.41 & 110.18 & 85.68 & 14.51 \\
\hline Jihočeský & 18.08 & 52.21 & 28.55 & 11.02 & 84.94 & 4.07 & 42.49 & 50.54 & 9.51 \\
\hline Plzeňský & 40.03 & 24.23 & 31.95 & 28.18 & 0.00 & 10.30 & 1.22 & 88.42 & 9.00 \\
\hline Karlovarský & 0.00 & 18.98 & 36.64 & 0.00 & 31.90 & 2.00 & 26.00 & 0.00 & 33.39 \\
\hline Ústecký & 15.73 & 112.18 & 17.20 & 5.16 & 107.21 & 114.10 & 0.00 & 0.00 & 0.00 \\
\hline Liberecký & 0.00 & 0.00 & 0.00 & 10.16 & 4.97 & 26.88 & 10.32 & 2.29 & 39.10 \\
\hline Královohradecký & $\mathrm{x}$ & $\mathrm{x}$ & 8.06 & 14.18 & 86.21 & 0.04 & $\mathrm{x}$ & 3.23 & $\mathrm{x}$ \\
\hline Pardubický & 0.30 & 0.00 & 14.20 & 0.00 & 93.83 & 0.00 & 70.00 & 9.14 & 0.00 \\
\hline Vysočina & 0.00 & 2.65 & 33.50 & 46.23 & 0.88 & 28.39 & 15.58 & 32.78 & 0.47 \\
\hline Jihomoravský & 1.03 & 0.94 & 139.15 & 10.48 & 0.01 & 0.46 & 11.61 & 16.12 & 1.62 \\
\hline Zlinský & 167.93 & 198.10 & 52.62 & 62.79 & 55.97 & 45.70 & 12.62 & 0.00 & 0.00 \\
\hline Olomoucký & 10.92 & 0.00 & 0.00 & 107.49 & 100.89 & 3.05 & 135.32 & 4.66 & 171.30 \\
\hline $\begin{array}{l}\text { Moravsko- } \\
\text { Slezský }\end{array}$ & 0.00 & 79.23 & 40.61 & 112.01 & 117.22 & 280.84 & 205.20 & 141.85 & 34.26 \\
\hline In total & 266.76 & 559.84 & 492.24 & 468.80 & 826.66 & 833.23 & 640.54 & 434.71 & 313.16 \\
\hline
\end{tabular}

Legend: $x=$ information is not available

The negative impact of traffic on soil is not only reflected in the chemical pollution of the road infrastructure surroundings, but also in the construction of roads and the whole transport network. As far as the land designated for construction is concerned, its original function has to be removed. Such land is converted into areas designated for construction, so, from the viewpoint of the Nature, it results in their degradation. The arable and forest land use figures clearly show (Table 5) that in 2004 almost 988 hectares were designated for road construction, which represented almost a fifth of the capital city's area, Prague.

The road alignment of important roads (nowadays mainly motorways) is considerably conditioned by terrain obstacles. It is easier to build such motorways mainly in the lowlands and valleys along important rivers; however, at these places there is often soil, which is highly valuable for agriculture. The motorways are commonly built in four lanes with a central reserve, i.e. that only the motorway itself and its adjacent strip will require the land use of an area of approximately 3 hectares per $1 \mathrm{~km}$ of motorway length. Apart 
from the motorway itself, other accompanying constructions are also included in the land use - ditches and embankments compensating the road alignment, grade-separated junctions, petrol stations, and other commercial activities linked to providing services to passengers, as well as constructions used to mitigate the negative impacts of traffic, like anti-noise screens or retention tanks for drain water.

\section{FLORA AND FAUNA}

Currently, due to transport development and increasing building activity, a debated topic is the impact on biological diversity, i.e. the number of flora and fauna species. Biodiversity is not only threatened by the reduced size of ecosystems or by the hunting of endangered species of animals, but also by the fragmentation of localities.

This fragmentation is understood as a division of natural localities into smaller and more isolated units, and therefore the survival of some species is threatened. One of the main reasons for locality fragmentations is, apart from agriculture and urbanization, mainly the construction and the use of transport infrastructure. The transport network divides the natural localities into smaller, isolated segments which are often smaller than some species need for their survival. The road then acts as a physical barrier for animals and is particularly restrictive for those species which need large areas for their living. This does not only include smaller animals, like amphibians, reptiles and small mammals, but also larger ones, like deer or wild boar, which are very often hit by vehicles. The pollution of the road environment by chemical pollutants influences the amount and species diversity of the soil micro flora and fauna (Tuháčková et al., 2001).

\section{LANDSCAPE PATTERN}

Quality and fast transport means shortening of the "perceived distance", because the destinations are much easier to be reached than years ago; therefore the deconcentration occurs for a lot of human activities, which were before concentrated in the cities. Currently, the process of suburbanization is the most typical demonstration; this is characterized by spatial urban growth in the outskirts, which is enabled by easily available individual car transport and which sometimes even develops into its uncontrolled form called "urban sprawl". This process is currently not occurring in a coordinated manner, because the role of land use planning is not powerful enough to ensure positive city development in terms of traffic and land use. The everyday problem of urban areas is the large number of cars, which the current city road network system is unable to accommodate anymore. In the case of huge cities, the move of residential areas and extensive commercial activities from the centres to the outskirts is apparent, without the appropriate connections to other urban areas, This causes increased demands on traffic, particularly individual road traffic, because these zones are usually designed to be predominantly available by personal vehicles, and public transport is usually not designed for these areas at all or only in a limited extent.

The landscape is very negatively influenced by the media advertisements, billboards, placed in the proximity of roads, particularly the busiest motorway sections, where the traffic flow exceeds 15000 vehicles per 24 hours. The advertisement messages are seen daily by tens of thousands of people, and, therefore, these places are very attractive for the advertising industry. The placement of legally constructed billboards, for which their owners signed the proper contracts, passed through the approval procedure of the administrative bodies, and, therefore, they are usually not located in inappropriate 
places. The Act No. 114/1992, Sb.,on the environment and landscape protection, states that it is not possible to place an advertising facility in places where it could have an impact on some important landscape features or some protected areas.

As a regulation complementing this Act, the Agency for the protection of the environment and landscape (AOPK) produced the "Methodology for the Evaluation of the Scenic Landscape" in 1999, which further specifies the terms such as natural, cultural, and historical characteristics of landscape, aesthetic value of the scenic landscape, natural value of landscape, cultural dominant features of landscape, etc.

However, besides legal advertising areas, there are a large amount of advertising facilities placed without the proper permits which are very often located in places unsuitable for these advertisements. It is a recent effort of the Road and Motorway Directorate of the Czech Republic, as a road administrator, to deal with this problem and restrict the number of billboards in road environment by up to $80 \%$. However, the owners of mega-boards, visible from over a long distance, are not too threatened by this effort, because their facilities are often located outside the designated safe area of roads and are often on private land. The assessment of the disturbance of landscape character has a big disadvantage due to the subjective assessments of specific situations. Therefore, there are unified rules for the determination of places where the advertising facility considerably affects landscape and where it should not be palced. An example of how a huge advertising panel could aesthetically violate the landscape is shown in a photo from the D1 motorway (see Figure 9 in the Appendix), which is, for comparison, supplemented with a computer photo-mounting where the advertising panel was removed.

\section{ACCIDENTS}

Dangerous chemical substances and chemical products (toxic, flammable, explosive), which can have a negative impact on human health and the environment, are handled with in everyday activities, including industry, trade, or during their transport.

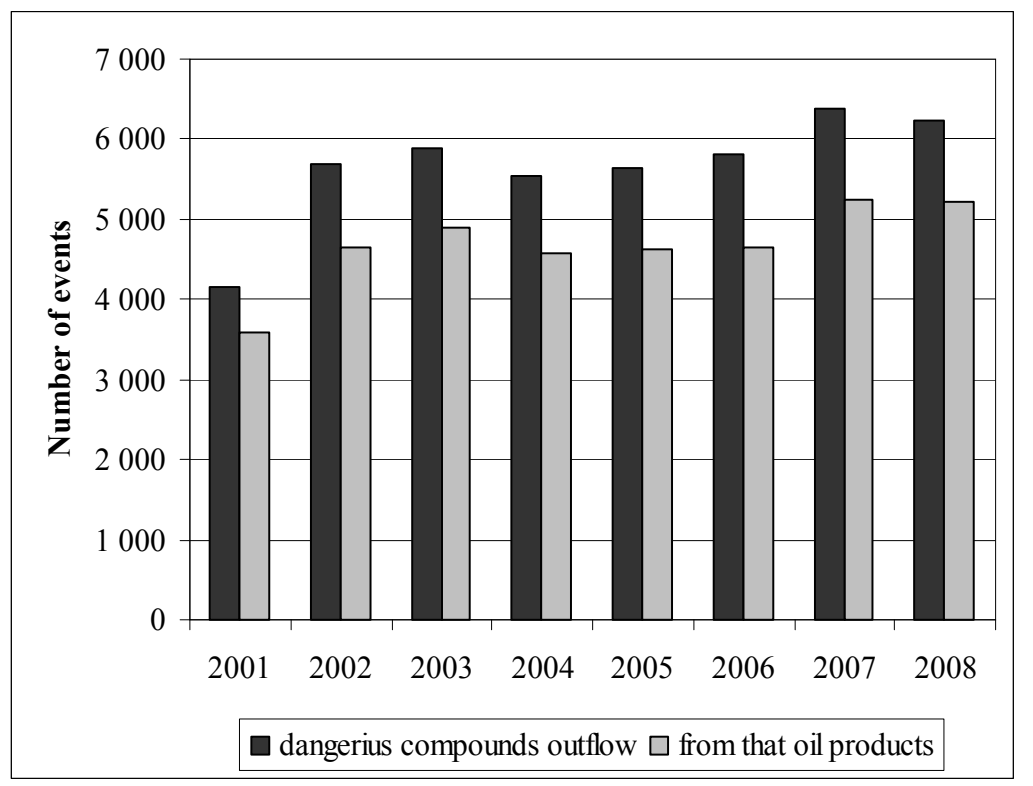

Figure 6: Number of releases of hazardous substances (HZS ČR, 2006). 
Due to the increasing traffic volume, there is more and more contamination of surface and ground water and the rock environment through vehicle accidents on roads. Their consequences are the leakage of dangerous materials - mainly fuel, motor oils, operating liquids, and also transported dangerous items, e.g. sulphuric acids. Currently, the majority of regulations concerning this issue have been cancelled and replaced by new regulations, or, they have been amended. Currently, Act No. 59/2006, Sb., on prevention of serious accidents, is mandatory, which is reflected in the development of the EU legislation, and, when it became effective, the earlier legislation regulations were superseded.

Transport of chemical, toxic, flammable, and explosive materials requires great attention, considering the risks of traffic accidents and the subsequent leakage of these materials during transport. All hazardous substances have their specific properties, and, consequently, they acquire different degrees of danger under different conditions, which is particularly important during their transportation and handling. The international road transport of hazardous goods complies with the The European Agreement concerning the International Carriage of Dangerous Goods by Road - ADR (Accord Dangerousness Route), which the Czech Republic also complies with. The International Carriage of Dangerous Goods Regulations is valid for the International Railway Transport of Dangerous Goods Regulation (RID) as a supplement to the unified legal regulations concerning the Agreement for the Carriage of Goods by Rail (CIM). Air transport of dangerous cargo follows regulations issued by the ICAO (International Civil Aviation Organization) and the regulations of the IATA (International Air Transport Association). The maritime transport of dangerous goods follows The International Maritime Dangerous Goods (IMDG Code).

Traffic accidents with oil products leakage of dangerous substances have the highest share in the creation of environmental accidents and crashes in transport. The following graph in Figure 6 shows the number of leakages of dangerous substances including oil products, with the intervention of fire brigade units between 2001 and 2005. The graph clearly shows the steady trend of leakage of dangerous chemical materials and oil products.

Each accident which causes the deterioration of environmental conditions needs to be assessed as an environmental accident which could cause the instability of the ecosystem (Kvarčák et al., 2000). The principles determined in the above-mentioned international regulations are the first step for the reduction of the number of collisions of vehicles transporting hazardous substances. But despite the observance of the regulations, there is still a risk of vehicle accidents, which could be increased, e.g. by aggravated climatic conditions, an increase in road traffic volume and consequent congestions. In order to avoid traffic accidents and subsequent environmental accidents, it is necessary to search for other ways to maintain safe traffic, which will lead to the minimization of environmental accidents.

\section{WASTE FROM TRANSPORT}

The production of huge amount of waste in the form of car wrecks is becoming one of the priority issues of every developed society. Car wrecks consist of up to $80 \%$ of recyclable materials, usable as secondary raw materials, e.g. metals or plastic. However, dangerous types of waste, such as leaded accumulators, oil filters, braking and antifreeze liquids, components containing mercury or $\mathrm{PCB}$, or brake pads containing asbestos, could have a negative effect on the environment through improper handling or leakage. In the Czech Republic, this issue is dealt with by Act No. 185/2001, Sb., which defines a car wreck as any complete or incomplete motor vehicle intended for the use on roads to transport people, animals, or goods which has become waste. Everyone who gets rid of waste is obliged to hand it over only to people who operate the devices for the re-use, 
removal, collection, and repurchase of car wrecks. The fundamental document which modifies the handling of this waste in the $\mathrm{EU}$ is the directive of the European Parliament and Council 2000/53/EC on vehicles with expired lifespan, and its appendices issued in the form of Decisions of the Commission of European Communities which are integrated in the Czech legislation in the form of the Waste Act (No. 185/2001, $\mathrm{Sb}$.), as amended by the Implementation Programme of the Czech Republic No. 4. The goal of all legal measures is to complete and improve the existing system of handling car wrecks, which could be an important source of secondary raw materials and energies.

The handling of car wrecks concerns several target groups on various legislative levels. These target groups are public (origin), local authorities, regional authorities (as an authority which issues licenses to facility operators for handling with this waste), and business entities (the authorized operators). The system of deregistration and environmental handling with scrapped passenger cars consists of the following steps. The principle is to hand the vehicle over to the collection network, then the gradual disassembly of the car wreck is executed so that the individual parts could be obtained separately, which individually are of higher value. Apart from this, it is possible to separate other waste containing hazardous substances, and thus reduce the total amount of dangerous waste. The crushing the vehicle body itself allows to gain pure steel scrap; this step could be alo replaced by cutting and pressing, which are less demanding in terms of operation and investments costs. Consistent sorting is an required for the higher level of metallurgical processing for non-ferrous metal components. Approximately 160 thousand cars are decommissioned yearly from operation in the Czech Republic, and up to 9 million vehicles in the whole EU (Božek et al., 2003, Šooš, 2006). Their material structure depends on a range of properties, such as the size and type of the vehicle, vehicle producer, model year, the age of the vehicle, or the efficiency of the processing and sorting technologies. In terms of quantity and recycling, ferrous metals (steel and cast-iron) are the most important components, which form around 62-68\%, then non-ferrous metals (for example aluminium, magnesium, copper) and their alloys at 3.5-6\%, other components such as paints, leather, wood, and paperboard make $5-15 \%$ of the car wreck weight. The proportion changes of individual components in the material structure are given by the technological development of the vehicles, where the share of plastic and the so-called light metals is currently increasing. An overview of the average material weight composition is shown in the following Figure 7.

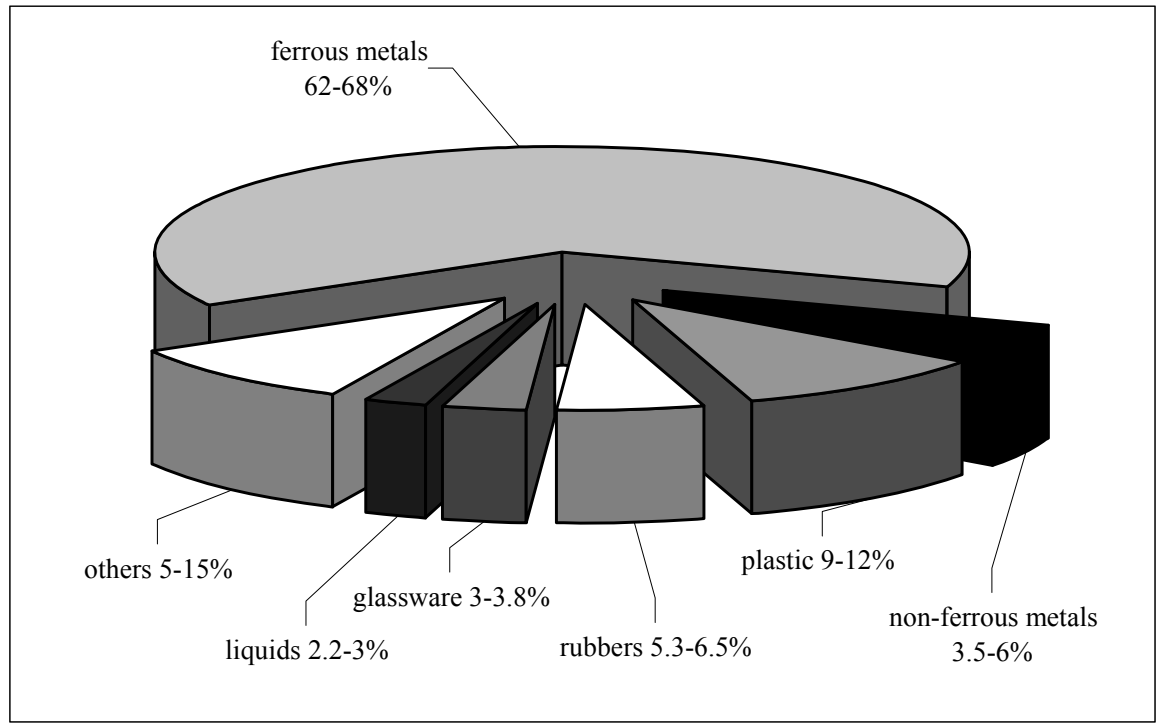

Figure 7: The average material vehicle weight composition (Polívka, 2004). 
In the EU countries, the total expenses for car disassembling are between $€ 150$ and 450 , and, with the use of waste crushers, which are mostly used in Germany, France, and Great Britain, between $€ 50$ and 70 per vehicle. Currently, approximately 80 collection points and 8 facilities for car wreck processing (disassembling devices + crushers) are in the Czech Republic. For the environmental processing of passenger cars with expired lifespan a fee amounting to CZK 1200 is charged. The costs for environmental car wreck processing range around $\mathrm{CZK}$ 3000, out of which approximately one third of the costs is used for the transport and handling, the other costs include the car wreck processing and the removal of the remaining parts, which include hazardous waste (Sýkora, 2005).

The waste produced by transport is currently a very topical issue, mainly due to the increase in the number of registered vehicles and their average age, which is currently 13.5 years. As far as the vehicle handling of future generations is concerned, waste production will still be on the rise, which has a range of negative effects. Therefore, the prevention and minimization of waste, which will lead to less harmful impact on the environmental, are very important issues concerning waste handling. There is also a connection with vehicle construction, which should, in the production stage, be focused on more effective use of secondary raw materials and energies, the share of materials with dangerous or toxic properties should be reduced in the maximum degree, so that new vehicles would be more environmentally friendly and have a higher potential for prevention, re-use, and material and energetic use (Adamec et al., 2006).

\section{SUMMARY}

Several thousands of various chemical compounds, often with mutagenic and carcinogenic effects, have been identified in the environment, out of which a considerable number comes from traffic (e.g. the combustion of fuel, abrasion of exposed parts of vehicles and the road surface). The concentrations of a some of them are regularly monitored and the Czech Republic has to reduce their amount according to its commitments within the EU membership. Nevertheless, the amount of the harmful compounds released to the environment by human activity is increasing rapidly. This unfavourable situation is apparent mainly in big cities with high traffic intensity where the considerable deterioration of air quality occurs, which influences the health of their citizens, mainly children and the elderly. In this respect, it is necessary to pay attention to this issue, which means to care more about the destination of the pollutants produced by traffic, and the associated potential health and environmental risks.

\section{ACKNOWLEDGEMENTS}

The study was supported by the Czech Ministry of Transport within the research project No. 04499457501 "Sustainable Transport - Chance for the Future, part 5 Transport and Environment" and R\&D project No. 1F54H/098/520 "The dustiness from traffic and its affects on air loading with particulate matter". The study was also supported by the Ministry of Environment of the Czech Republic within R\&D project No. SP/1a3/55/08 "Morphology, chemical composition and toxicological assessment of road dust and particulate matter including sources identification". 


\section{REFERENCES}

Adamec, V., Dufek, J., 2002. Transport share on air polluting emissions in the Czech Republic. In 11th International Symposium Transport and Air Pollution: Proceedings, Volume II., Graz (Austria), 19. - 21. 6. 2002. Graz (Austria): TU Graz, pp. 81-82. ISBN 3-901351-59-0.

Adamec, V., Dufek, J., Jedlička, J. et al., 2005. Znečištění ovzduší z dopravy. Ochrana ovzduši, príloha Kompendium ochrany kvality ovzduši, část 5, roč. 17, č. 2, 27 p. ISSN 1211-0337. (in Czech)

Adamec, V., Dvořáková, P., Jedlička, J. et al., 2006. Dangerous Matter and the Traffic Wastes. In Proceedings of the 1st International Scentific Conference Safety Engineering 2006, Ostrava, 17.-19.10. 2006. Ostrava: VŠB-TU, FBI, pp. 1-11. ISBN 80-248-1185-5, ISSN 1801-1764.

Adamec, V., Huzlík, J., Kohoutek, J. et al., 2004. Content of Trace Elements and Polycyclic Aromatic Hydrocarbons in Particulate Matter and their Vertical Distribution in StreetCanyon. In 19th International Conference Air Protection: proceedings, Vysoké Tatry Štrbské Pleso (Slovakia), 24. - 26. 11.2004. Bratislava (Slovakia): Dom techniky ZSVTS, pp. 175 -179. ISBN 80-233-0500-X.

Adamec, V., Huzlík, J., Ličbinský, R. et al., 2007. Prašnost dopravy a její vlivy na imisní zatižení ovzduši suspendovanými částicemi (Výroční zpráva projektu VaV 1F54H/098/520 za rok 2006). Brno: Centrum dopravního výzkumu, v.v.i., 93 p. (in Czech)

Adamec, V., Huzlík, J., Ličbinský, R., Schwarzová, M., 2007. Variations of particulate matter concentrations in dependence on climatic conditions. In European Aerosol Conference 2007 [CD-ROM], Salzburg (Austria), 9. - 14. 9. 2007. Salzburg (Austria): European Aerosol Assembly (EAA), Gesellschaft Für Aerosolforschung (GAeF), Universität Salzburg.

Adamec, V., Cholava, R., Vlčková, J. et al., 2005. Udržitelná doprava - šance pro budoucnost, část 5 Doprava a životni prostředí. (Průběžná zpráva výzkumného záměru MD ČR č. 4499457501). Brno: Centrum dopravního výzkumu, 52 p. (in Czech)

Adamec, V., Kopecký, L., Huzlík, J. et al., 2005. Suspended Particles and their Origin in Air Samples. In 14th International Symposium Transport and Air Pollution, Volume I, Graz (Austria), 1. - 3. 6. 2005. Graz (Austria): Graz University of Technology, pp. 347-352. ISBN 3-902465-16-6.

Adamec, V., Ličbinský, R., Huzlík, J., 2006. Chemical composition of $\mathrm{PM}_{2.5}$ emitted from transport. In JOUMARD, R. (ed.) Environnement \& Transports / Environment \& Transport: Vol. 2 Poster communications. Actes INRETS n¹07, Reims (France), 12. - 14. 6. 2006. Bron cedex (France): INRETS, pp. 96-100. ISSN 0769-0266, ISBN 2-5782-639-7.

Adamec, V., Šucmanová, M., Marešová, V. et al., 2004. Antropogenic input of platinum metals into the environment. In SETAC Europe 14th Annual Meeting, Praha (Czech Republic), 18. - 22. 4. 2004. Brussels (Belgium): SETAC Europe, p. 284. 
Barefoot, R. R., 1997. Determination of platinum at trace levels in environmental and biological materials. Environmental Science \& Technology, vol. 31, no. 2, pp. 309 314. ISSN 0013-936X.

Božek, F., Urban, R., Zemánek, Z., 2003. Recyklace. Vyškov: Moravia Tisk, 238 p., ISBN 80-238-9919-8. (in Czech)

Braaten, D.A., Paw, U.K.T., Shaw, R.H. 1990. Particle resuspension in a turbulent boundary layer observed and modelled. J. Aerosol Sci. 21, pp. 613-628. ISSN: 0021-8502.

Dreher K. L. et al., 2003. Nanotechnology implications in health and the environment. In Nanotechnology and the Environment : Report of the National Nanotechnology Initiative Workshop, Arlington, VA (USA), 8. - 9. 5. 2003. Arlington, VA (USA): National Science and Technology Council, pp. 31 - 36.

Dufek, J., Huzlík, J., Adamec, V., 2001. Metodika pro stanovení emisní zátěže látek znečištujicich ovzduši v České republice. Brno: Centrum dopravního výzkumu, 21 p. (in Czech)

Farago, M.E., Kanavagh, R. Blanks, R., 1996. Platinum metal concentrations in urban road dust and soil in the United Kingdom. Fresenius' Journal of Analytical Chemistry, Vol. 354, pp. 660 - 663. ISSN 0937-0633.

Gómez, B, Gómez, M., Sanchez, J.L. et al. 2001. Platinum and rhodium distribution in airborne particulate matter and road dust. Science of the Total Environment, vol. 269, pp. 131 - 144. ISSN 0048-9697.

Harrison, R.M., Smith, D.J.T., Luhana, L., 1996. Source Apportionment of Atmospheric Polycyclic Aromatic Hydrocarbons Collected from an Urban Location in Birmingham, U.K. Environmental Science \& Technology, vol. 30, no. 3, pp. 825-832. ISSN 0013936X.

Harrison, R.M., Tilling, R., Callén Romero, M.C. et al., 2003. A Study of Trace Metals and Polycyclic Aromatic Hydrocarbons in the Roadside Environment. Atmospheric Environment, vol. 37, no. 17, pp. 2391-2402. ISSN 1352-2310.

HZS ČR 2006. Statistická ročenka 2005 [on-line]. Praha: MV-generální ředitelství HZS ČR, prŕloha časopisu 112, č. 3, 36 p. [cit. 2007-06-11]. Dostupné z: http://www.mvcr.cz/statistiky/2006/hzsrok05.pdf (in Czech)

Janssen, N.A., van Manson, D.F.M., van der Jagt, K. et al., 1997. Mass concentrations and elemental composition of airborne particulate matter at street and background locations. Atmospheric Environment, vol. 31, no. 8, pp. 1185 - 1193. ISSN 1352-2310.

Jedlička, J., et al., 2009. Studie o vývoji dopravy z hlediska životního prostředí v České republice za rok 2008. Brno: Centrum dopravního výzkumu, v.v.i, 118 p. (in Czech)

Krzyzanowsky, M., Kuna-Dibbert, B., Schneider, J. (Eds.), 2005. Health effects of transportrelated air pollution. Copenhagen: WHO Europe. ISBN 92-890-1373-7.

Kvarčák, M., Vavrečková, J., Žemlička, Z., 2000. Likvidace ropných havárií. Ostrava: SPBI Spektrum, 106 p. ISBN 80-86111-61-X. (in Czech) 
Lamoree, D.P., Turner, J.R., 1999. PM emissions emanating from limited-access highways. Journal of the Air \& Waste Management Association, vol. 49, Special Issue, pp. 85 - 94. ISSN 1047 - 3289.

Legret, M., Odieb, L., Demarea, D. et al., 2005. Leaching of heavy metals and polycyclic aromatic hydrocarbons from reclaimed asphalt pavement. Water Research, vol. 39, no. 15 , pp. 3675-3685. ISSN 0043-1354.

Ličbinský, R., Schwarzová M., Provalilová I., 2007. Kontaminace vod polutanty obsaženými v konstrukčních vrstvách vozovek (Závěrečná zpráva o realizaci projektu 1P050C003). Brno: Centrum dopravního výzkumu, v.v.i., 15 p. (in Czech)

Martuzzi, M., Galasi, C., Ostro, B. et al., 2002. Health Impact Assessment of air pollution in the eight major italian cities. Roma: WHO, $61 \mathrm{p}$.

Nicholson, K.W. 1988. Review article: a review of particle resuspension. Atmospheric Environment, vol. 22, no. 12, pp. 2639 - 2651. ISSN 1352-2310.

Polívka, E., 2004. Realizační program ČR č. 4 pro nakládání s autovraky. Praha: SUNEX, s.r.o., 42 p. (in Czech)

Runge, I., Wright, R.M., Urish, D.W., 1989. Modelling sodium and chloride in surface streams during base flows. Journal of Environmental Engineering, vol. 115, no. 3, pp. 608 - 619. ISSN: 0733-9372.

Salma E., Maenhaut, W., 2006. Changes in elemental composition and mass of atmospheric aerosol pollution between 1996 and 2002 in a Central European city. Environmental Pollution, vol. 143, no. 3, pp. 479 - 488. ISSN 0269-7491.

Sansalone, J.J., Buchberger, S.G., 1995. An infiltration device as a best management practice for immobilizing heavy metals in urban highway runoff. Water Science and Technology, vol. 32, no. 7, pp. 119 - 125. ISSN 0273-1223.

Shinya, M., Tsuchinaga, T., Kitano, M. et al., 2000. Characterization of heavy metals and polycyclic aromatic hydrocarbons in urban highway runoff. Water Science and Technology, vol. 42, no. 7-8, pp. 201 - 208. ISSN 0273-1223.

Smith, J.A., Sievers, M., Huang, S., Yu, S.L. et al., 2000. Occurrence and phase distribution of polycyclic aromatic hydrocarbons in urban storm-water runoff. Water Science and Technology, vol. 42, no. 3-4, pp. 383 - 388. ISSN 0273-1223.

Sýkora, O., 2005. Autovraky - rok 2005. Odpadové fórum, č. 10, pp. 11 - 12. ISSN 12127779. (in Czech)

Šebor, G., Píša, V., Horníček, K., 2002. Mefa 02 - Program pro výpočet emisních faktorů pro motorová vozidla [software]. Praha: Ministerstvo životního prostředí. (in Czech)

Šooš L., 2006. Zber a spracovanie starých vozidel na Slovensku. Odpadové fórum, č. 10, pp. 14 -16. ISSN 1212-7779. (in Slovak) 
Tuháčková, J., Cajthalm, T., Novák, L. et al., 2001. Hydrocarbon deposition and soil microflora as affected by highway traffic. Environmental Pollution, vol. 113, no. 3, pp. 255 - 262. ISSN 0269-7491.

Vallius, M., Janssen, N.H.N., Heinrich, J., et al., 2005. Sources and elemental composition of ambient PM2.5 in three European cities. Science of the Total Environment. 337, pp. 147 - 162. ISSN 0048-9697.

Weijer, E. P., Even A., Kos, G.P.A. et al., 2001, Particulate matter in urban air: health risks, instrumentation and measurements and political awareness. Amsterdam: Ecn-Clean Fossil Fuels Air Quality, 68 p. ECN-R--01-002.

WHO, 2000. Air quality guideline for Europe. 2nd ed. Copenhagen: WHO, 274 p., ISBN $92-$ 890-1358-3.

Yli-Tuomi, T., Aarnio, P., Pirjola, L. et al., 2005. Emissions of fine particles, $\mathrm{NO}_{\mathrm{x}}$, and CO from on-road vehicles in Finland. Atmospheric Environment, vol. 39, no. 35, pp. 6696-6706. ISSN 1352-2310.

Zákon č. 86/2002 Sb. o ochraně ovzduší a o změně některých dalších zákonů (zákon o ochraně ovzduší). (in Czech)

Zereini, F., Skerstupp, B., Alt, F. et al., 1997. Geochemical behaviour of platinum-group elements (PGE) in particulate emissions by automobile exhausts catalysts: experimental results and environmental investigations. Science of the Total Environment, vol. 206, no. 2, pp. 137 - 146. ISSN 0048-9697. 